\title{
Pemberdayaan Perempuan Melalui Sekolah Wirausaha Aisyiah Kabupaten Semarang
}

\author{
Women Empoweriment Through Aisyiah Entrepreneurship Schools \\ in Semarang Regency \\ Sih Darmi Astuti ${ }^{1}$, Dwi Eko Waluyo ${ }^{2}$, Herry Subagyo ${ }^{3}$ \\ Fakultas Ekonomi dan Bisnis Universitas Dian Nuswantoro \\ 1astuti_sda.@dsn.dinus.ac.id.2dwi.eko.waluyo@dsn.dinus. ac.id, \\ 3herry.subagyo@dsn.dinus.ac.id
}

\begin{abstract}
Abstrak
Laporan mengenai rendahnya keterlibatan perempuan dalam partisipasi ekonomi di Indonesia mendorong Aisyiah, Organisasi sosial kemayarakatan di kabupaten Semarang mengembangkan sekolah kewirausahaan. Sekolah ini dimaksudkan untuk memfasilitasi para perempuan yang memiliki minat menjalankan usaha. sebagai langkah pertama, organisasi ini telah melakukan pelatihan dengan topik "Pemberdayaan Perempuan Melalui Sekolah Kewirausahaan" pelatihan ini diikuti oleh 35 orang peserta. Materi yang diberikan meliputu: Pentingnya peran perempuan dalam ekonomi keluarga, Kewirausahaan dan Pengenalan media sosial. Berdasarkan hasil evaluasi menunjukan bahwa para peserta merasakan manfaat dari pelatihan ini sehingga membangkitkan semangat untuk terus meningkatkan peran dalam ekonomi keluarga melalui berwirausaha
\end{abstract}

Kata kunci: Aisyiah, pemberdayaan perempuan, sekolah kewirausahaan

\begin{abstract}
Reports of the low involvement of women in economic participation in Indonesia prompted Aisyiah, a social organization in Semarang district to develop an entrepreneurship school. This school is intended to facilitate women who have an interest in running a business. As a first step, this organization has conducted training with the topic "Empowering Women Through Entrepreneurship Schools" This training was attended by 35 participants. The material provided includes: The importance of the role of women in the family economy, entrepreneurship and the introduction of social media. Based on the results of the evaluation showed that the participants felt the benefits of this training so that it would arouse enthusiasm to continue to increase the role in the family economy through entrepreneurship.
\end{abstract}

Keywords: Aisyiah, women empowerment, entrepreneurship school

\section{PENDAHULUAN}

Economic Forum Masalah Global Gender gap pada tahun 2017 merilis laporanya bahwa Indonesia menempati urutan 109 dari144 negara terkait dengan keterlibatan perempuan dalam partisipasi ekonomi dan kesempatan berusaha. Laporan tersebut menggambarkan bahwa perempuan di indonesia belum sepenuhnya mendapatkan kesempatan dalam mendapatkan peluang kerja dan peluang berusaha. Rendah kesempatan dan keterlibatan perempuan tersebut tidak hanya berdampak pada perekonomian, tapi juga berdampak pada masalah sosial yang lain, ketergantungan ekonomi perempuan terhadap laki-laki seringkali menyebabkan perempuan tidak berdaya ketika terjadi kekerasan dalam keluarga atau tidak dilibatankan dalam pengambilan keputusan. 
Realitas di masyarakat menunjukkan bahwa perempuan menjadi pelaku ekonomi yang sangat potensial dalam bisnis usaha mikro, kompetensi perempuan dalam bisnis mikro ini ditunjang dengan sifat yang dimiliki, misalnya: Telaten, sperti kita ketahui bahwa pada umumnya perempuan lebih teliti dalam menjalankan usaha, perempuan lebih memperhatikan hal kecil yang seringkali dianggap sepele oleh lelaki. Membangun jejaring perempuan lebih unggul dibandingkan dengan laki-laki, karena perempuan pada umumnya memiliki kemampuan sosial dan mudah bergaul sehingga mudah untuk menjaring pelanggan, disamping itu, perempuan lebih jeli melihat peluang usaha, seringkali peluang usaha yang dianggap sepele oleh laki-laki dapat mendapatkan keuntungan dan sukses ketika dilakukan oleh perempuan. Ulet, perempuan tidak mudah putus asa ketika mengalami kegagalan, memiliki daya juang yang lebih tinggi dan lebih sabar. Keunggulan perempuan tersebut menjadi modal dasar yang sangat penting ketika perempuan diberdayakan dan diberi kesempatan untuk mengembangkan dirinya sebagai wirausaha.

Menyadari potensi perempuan dalam berwirausaha, organisasi kemasyarakatan Aisyiah, organisasi yang mewadahi perempuan dalam kegiatan sosial dan keagamaan terpanggil untuk memberdayakan kesejahteraan para anggotanya. Pengurus Aisyiah bekerjasama dengan Tim FEB Udinus melakukan pelatihan kewirausahaan dan penggunaan media sosial sebagai sebagai media promosi kegiatan organisasi dan mempromosikan hasil karya anggota Aisyiah yang sebagian besar memiliki aktivitas ekonomi sebagai wirausaha skala mikro dan kecil. Bagi anggota organisasi Aisyiah pelatihan ini diharapkan dapat meningkatkan ketrampilan dalam menggunakan media sosial untuk mempromosikan hasil usaha sehingga dapat menjangkau pasar yang lebih luas. Sedangkan bagi pengurus Aisyiah, pelatihan ini dapat digunakan untuk meningkatkan ketrampilan menggunakan komputer untuk kegiatan keorganisasian (administrasi) dan sosialisasi kegiatan melalui media sosial.

\section{METODE PELAKSANAAN}

Kegiatan Pelatihan ini bertujuan untuk meningkatkan softskill dan hardskill peserta pelatihan, yaitu Anggota dan pengurus Asyiah kabupaten Semarang. Luaran kegiatan berupa pemahaman tentang pentingnya peran perempuan dalam perekonomian keluarga, Kewirausahaan sebagai alternatif untuk meningkatkan kesejahteraan keluarga. dengan kemandirian berusaha dapat mengurangi ketergantungan terhadap laki-laki. kegiatan ini diawali dengan survey awal dan diskusi dengan pengurus Aisyiah, kegiatan ini dilakukan untuk mendapatkan masukan dan rancangan kegiatan yang dibutuhkan oleh peserta latihan. Kegiatan pelatihan ini menggunakan pendekatan: Ceramah dan diskusi melalui tahapan sebagai berikut:

a. Tim pengabdian melakukan survey lokasi untuk mendapatkan gambaran tentang peserta pelatihan, untuk itu tim berdiskusi dengan pengurus Aisyiah kabupaten Semarang.

b. Persiapan Kegiatan yang dilaksanakan oleh tim pengabdian untuk merencanakan kegiatan yang mencakup penetapan waktu, materi pelatihan dan teknis pelaksanaan kegiatan

c. Setelah diperoleh kepastian waktu dan tempat pelaksanaan, Tim Pengabdian dibantu oleh pengurus Aisyiah mengundang anggota Aisyiah untuk menjadi peserta pelatihan dengan target peserta 35 orang.

d. Pelatihan pada sesi pertama menggunakan metode ceramah dan diskusi, pada sesi ini fasilitator menjelaskan tentang pentingnya perempuan memiliki sumber daya ekonomi yang dapat mengurangi ketergantungan terhadap laki-laki. Sesi ini dimaksudkan untuk membekali para peserta dengan menumbuhkan motivasi serta menjelaskan pentingnya peran perempuan dalam ekonomi keluarga.

e. Pelatihan pada sesi kedua, adalah Kewirausahaan sebagai alternatif meningkatkan kesejahteraan keluarga. sesi ini dimaksudkan untuk menanmkan jiwa kewirausahaan antara lain :kreatif, inovatif dan ulet. 
f. Pelatihan pada sesi ketiga, pentingnya media sosial sebagai media untuk mempromosikan produk dan kegiatan organisasi. Sesi ini dimaksudkan untuk memberi ketrampilan yang terkait dengan penggunaan internet untuk mengenalkan dan mempromosikan kegiatan organisasi dan hasil usaha peserta.

\section{HASIL DAN PEMBAHASAN}

Tahap awal kegiatan ini dilakukan diskusi dengan pengurus Aisyiah untuk mengindentifikasi permasalahan yang dihadapi oleh anggota Aisyiah. Iidentifikasi ini penting dilakukan untuk menentukan materi pelatihan yang sesuai dengan kebutuhan sehingga kegiatan ini dapat memberi manfaat bagi peserta pelatihan. Terkait dengan itu, Ife \& Tesoriero (2008) menjelaskan bahwa dalam proses pemberdayaan masyarakat pihak eksternal (fasilitator) berperan untuk memudahkan masyarakat dalam menentukan kebutuhan mereka sendiri.

Sebagaimana dijelaskan, peserta pelatihan ini adalah anggota dan pengurus Aisyiah Kabupaten Semarang yang telah memiliki dan berminat untuk berwirausaha, dengan demikian para peserta memeliki kebutuhan untuk mengembangkan usahanya. Berdasarkan kebutuhan tersebut diputuskan materi yang diberikan adalah 1) motivasi, materi ini diharapkan dapat menumbuhkan motivasi peserta yang berkaitan dengan perannya sebagai perempuan pelaku usaha. 2) Kewirausahaan, mteri ini diharapkan dapat meningkatkan semangat dan jiwa wirausaha. 3) Penggunaan media sosial, materi ini dimaksudkan untuk meningkatkan ketrampilan peserta dalam usaha memperluas pasar melalui media sosial.

Pada sesi pertama peserta diberi wawasan tentang realitas di masyarakat bahwa perempuan di indonesia belum sepenuhnya mendapatkan kesempatan dalam mendapatkan peluang kerja dan peluang berusaha. Rendah kesempatan perempuan tersebut tidak hanya berdampak pada ekonomi keluarga, tapi juga berdampak pada masalah sosial, ketergantungan ekonomi perempuan terhadap laki-laki seringkali menyebabkan perempuan tidak berdaya ketika terjadi kekerasan dalam keluarga. oleh karena itu perempuan harus menjadi manusia produktif, menjadi manusia produktif tidaklah mudah dan membutuhkan upaya yang cukup gigih. Manusia produktif adalah manusia yang menghasilkan sesuatu, melahirkan pikiran yang bermanfaat, tidak konsumtif, manusia yang dapat berkreasi dan berkarya, yang bisa mengembangkan kemampuan diri serta bermanfaat bagi sekitarnya (Jannah, 2011). Manusia ditunjuk oleh Tuhan sebagai khalifah untuk menjalankan amanah sebagai kholifah dimuka bumi, status sebagai khalîfah menunjukkan penghargaan yang tinggi terhadap manusia, kaum perempuan sebagai manusia, memiliki kewajiban sebagai khalifah dimuka bumi, perempuan sebagai diri pribadi, istri, ibu dan bagian dari masyarakat menuntut untuk menjadi perempuan yang produktif dan berkualitas sehingga keberadaan perempuan menjadi berdaya dan tidak menjadi manusia lemah sebagaimana stigma selama ini.

Pada sesi kedua materi yang diberikan tentang penting perempuan memiliki jiwa kewirausahaan yang mencakup: sikap, keterampilan dan pengembangan diri ke arah kemandirian hidup. Ada beberapa faktor yang mempengaruhi perilaku kewirausahaan yaitu (1) keuletan, keuletan merupakan sumber keberhasilan usaha dengan modal kerja fisik dan akal, kita harus ulet dan mampu memulai usaha. Orang ulet tidak mudah putus asa, dan juga selalu yakin bahwa kegagalan adalah guru tebaik untuk maju, kegagalan harus dihadapi dengan sikap. (2) kreatif dan inovatif, kreativitas merupakan sebuah proses yang dikembangkan dan ditingkatkan, namun kemampuan ini berbeda dari satu orang terhadap orang lain (Karwati, 2017). Kewirausahaan merupakan kemampuan kreatif dan inovatif yang dijadikan dasar, kiat, dan sumber daya untuk mencari peluang menuju sukses (Suryana, 2003). Inti dari kewirausahaan adalah kemampuan untuk menciptakan sesuatu yang baru dan berbeda melalui berpikir kreatif dan bertindak inovatif untuk menciptakan peluang".

Sesi terakhir dalam pelatihan ini adalah penggunaan internet sebagai media sosial yang dapat digunakan sebagai sumber informasi dan media untuk menyampaikan informasi. Metode yang digunakan dalam sesi ini adalah praktik mengakses internet, memilih media, menguduh 
informsi dan mengunggah informasi. Sebagai materi terakhir, materi merupakan yang paling menarik peserta pelatihan. Melalui pelatihan ini para peserta menjadi mengerti bagaimana internet dapat menjadi sumber belajar semua kebutuhan yang diinginkan. Sebelum mengikuti pelatihan ini para peserta sudah mengenal internet, tetapi belum mengerti apabila internet dapat memberikan informasi yang begitu banyak menyangkut semua aspek kehidupan.

Setelah pelatihan, selanjutnya dilakukan evaluasi. Berdasarkan hasil evaluasi yang dilakukan oleh tim bersama dengan pengurus Aisyiah, maka menunjukan adanya minat dan keseriusan peserta pelatihan, maka untuk selanjutnya diputuskan untuk dilakukan pendidikan dan pelatihan secara rutin dan sistematis, dengan menggunakan kurikulum yang disusun sesuai dengan kebutuhan mereka. Agar supaya kegiatan usaha para peserta pelatihan dapat dipantau perkembanganya, perlu juga dilakukan pendampingan pada setiap usaha peserta pelatihan. Untuk itu tim akan melibatkan beberapa perguruan tinggi yang tergabung dalam Asosiasi dosen untuk pengembangan ekonomi dan keuangan (ALFED)

\section{KESIMPULAN}

Pelaksanaan pemberdayaan perempuan diawali dengan melakukan dentifikasi permasalahan peserta pelatihan. Dengan mengetahui kebutuhan peserta, maka tim dapat mengembangkan materi pelatihan sesuai dengan kebutahanya. Pengembangan materi yang dirancang atas dasar kebutuhan peserta palatihan akan menarik minat dan keseriusan peserta. Berdasarkan hasil evaluasi yang telah dilakukan dapat disimpulkan bahwa dengan pelaksanaan pelatihan ini para peserta merasakan:

1. Termotivasi untuk terus berusaha dan mengembangkan usaha, tidak mudah patah semngat dan berusah untuk menjadi perempuan yang memiliki peran dalam perekonomian keluarga.

2. Untuk menjadi sukses dibutuhkan sikap dan jiwa kewirausahaan, kreatif, inovatif, tidak mudah putus asa dan mempunyai semangat yang tinggi

3. Untuk menjalankan dan mengembangkan usaha, dibutuhkan ketrampilan yang memadai serta mengikuti perkembangan teknologi, antara lain adalah menggunakan komputer untuk akses internet untuk memperkenalkan produk hasil usahanya pada pasar yang lebih luas

\section{SARAN}

Berdasarkan pengamatan dan hasil evaluasi menunjukan antusianisme para peserta sangat tinggi, dapat mengikuti dan memahami seluruh materi yang diberikan, hal ini bisa dilihat dari banyaknya peserta yang mengajukan pertanyaan dan diskusi yang cukup menarik diantara para peserta. Untuk itu perlu dilanjutkankan proses pelatihan berikutnya sehingga seluruh materi dapat diberikan secara utuh. Mengingat bahwa para peserta sebagian besar memiliki usaha, sebaiknya dilakukan pendampaingan usaha, dengan demikian kemajuan usaha bisa dipantau perkembanganya.

\section{Daftar Pustaka.}

[1] Astuti, M. (2018). Pemberdayaan perempuan miskin berbasis pemanfaatan sumber daya lokal melalui pendekatan sosial enterpreneurship. Sosiokonsepsia, Jurnal Ilmiah VISI PGTK PAUD dan Dikmas - Vol. 13, No. 2, Desember

[2] Budimanta, Arif (2003), Cetak Bitu Pengelolaan Community Development, ICSD, Jakarta 
[3] Hasanatul, Jannah (2011). "Pemberdayaan Perempuan Dalam Spiritualitas Islam" Jurnal KARSA, Vol. 19 No. 2

[4] Hernawati, Kuswari, "Pengenalan Internet Dan Blog Wordpress" Modul Pengenalan Internet tahun 2010

[5] Hubeis, A. V. S. (2010). Pemberdayaan perempuan dar masa ke masa. Bogor: IPB Press

[6] Ife, J. \& Tesoriero, F. (2008). Community development: alternatif pengembangan masyarakat di era globalisasi. Yogyakarta: Pustaka Pelajar

[7] Kamil, M. (2009). Mengembangkan pendidikan nonformal melalui PKBM di Indonesia: Sebuah pembelajaran dari kominkan di Jepang. Bandung: Alfabeta.

[8] Lilis Karwati \& Mustakim (2018), Model pemberdayaan masyarakat terintegrasi dengan kearifan dan nilai budaya lokal melalui pendekatan sosial entrepreneurship, Jurnal Ilmiah VISI PGTK PAUD dan Dikmas - Vol. 13, No. 2, Desember

[9] Priyanto, S.H. (2009). Mengembangkan pendidikan kewirausahaan di masyarakat. Jurnal PNFI Volume I No. 1, November 2009, 57-82

[10] Suryana, Dr. (2003). Kewirausahaan pedoman praktis, kiat dan proses menuju sukses. Jakarta: Salemba Empat

\section{UCAPAN TERIMA KASIH}

Terimakasih tim penulis sampaikan kepada LPPM (Lembaga Penelitian dan Pengabdian kepada Masyarakat) Udinus yang telah memberikan bantuan pendanaan untuk terlaksananya Pengabdian kepada Masyarakat ini.

Lampiran : foto Kegiatan

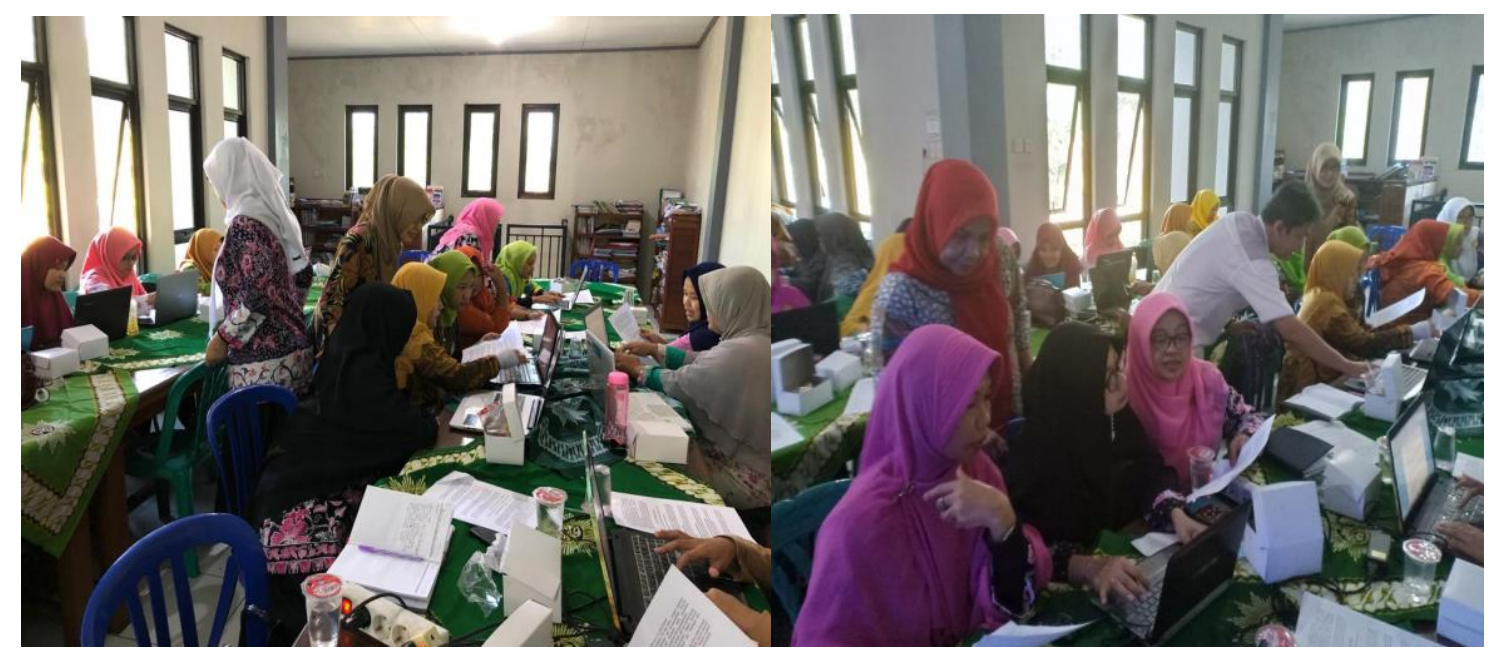


Abdimasku, Vol. 3, No. 1, Januari 2020: 71-76

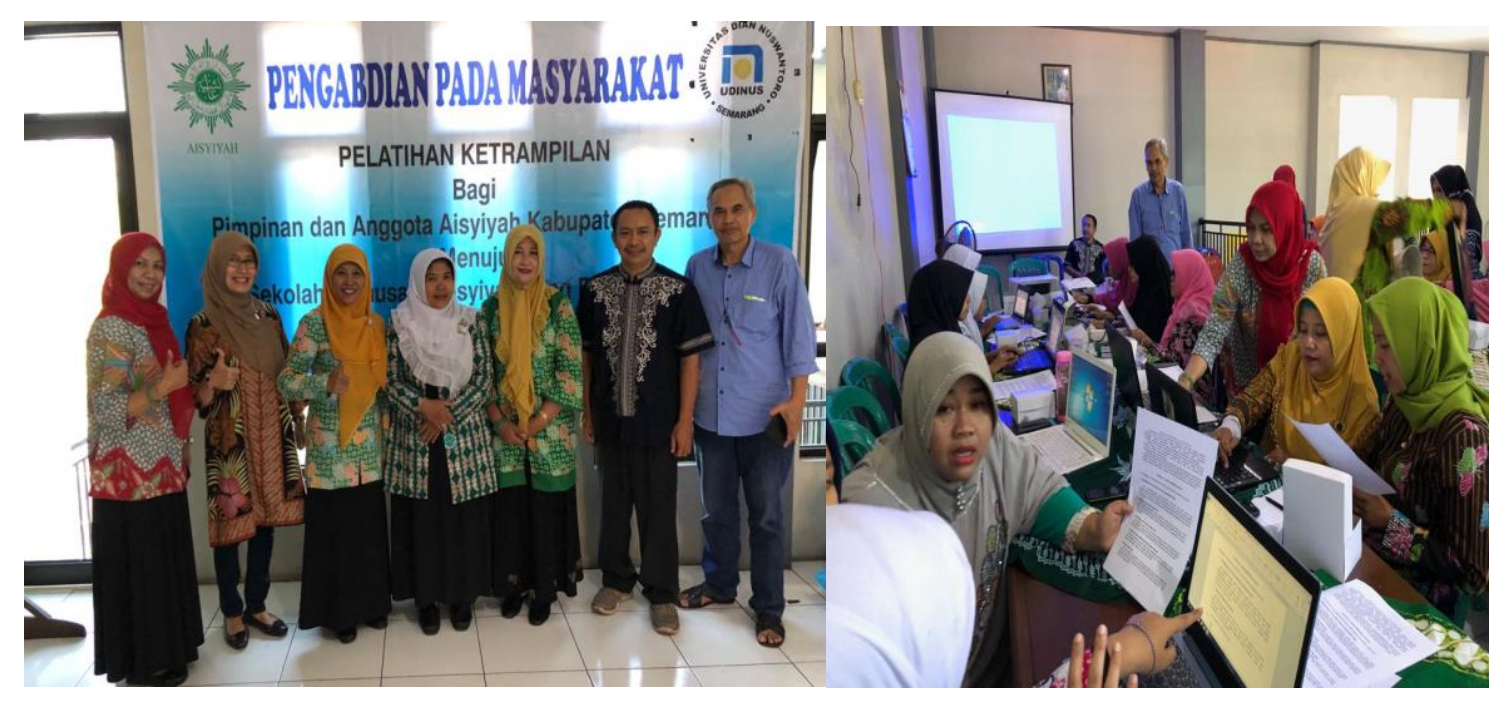

